Journal of Gender Studies, 2015

VOL . XX, NO . X, 1-12

http://dx.doi.org/10.1080/09589236.2015.1105738

Published online $4^{\text {th }}$ Nov 2015

\title{
Gender Flexible Pedagogy in Early Childhood Education
}

Jo Warin (Lancaster University) and Vina Adriany (University of Education, Indonesia)

ARTICLE HISTORY

Received 30 April 2015

Accepted 6 October 2015

KEYWORDS

Gender; early childhood;

pedagogy; role modelling

The corresponding author is Jo Warin,j.warin@lancaster.ac.uk, Department of Educational Research, Lancaster University, LA1 4YL

\section{Abstract}

Early childhood education (ECE) has long been recognized as one of the most gendered professions. This paper aims to examine how far ECE can become a space to deliver 'gender flexible pedagogy', a concept that incorporates ideas about staff modelling of alternative forms of masculinities and femininities, the value of a mixed gender workforce, and explicit gender teaching within curricula. The theoretical underpinnings of this concept are discussed drawing on data collected in discussions with pre-school teachers in order to understand the potential of this principle and identify how it can be practiced. The paper is based on two different interview based studies, one conducted in an Indonesian kindergarten and the other with Swedish preschool pedagogues. The findings suggest that gendered practices in ECE are 
rooted in teachers' implicit gender beliefs influenced by larger socio-political discourses. Early childhood educators must develop an explicit gender consciousness before they can deliver a gender conscious pedagogy.

\section{Gender Flexible Pedagogy in Early Childhood Education}

\section{Introduction}

The purpose of this paper is to consider the concept of a 'gender flexible pedagogy', an idea that we have identified in order to apply Butler's theoretical approach to gender and her emphasis on gender flexibility (Butler, 1990). An international network of gender researchers, funded by the Swedish Research Council from 2011 to 2014 created a forum for comparing and discussing research on gender and teaching across a range of international early childhood education sites and led to a focus on gender flexible teaching. We explore the theoretical underpinnings of this concept and discuss its potential by drawing on data from two small-scale interview studies with Early Childhood Education teachers, one in Sweden and one in Indonesia, in order to understand what it might mean and how it can be put into practice.

Our understanding of this concept emphasizes how early childhood educators, both men and women, can model a flexible approach to the performance of gender which disrupts prescriptions for men to model masculinities and women to model femininities. The concept of gender flexible teaching also incorporates ideas about the resources and activities that young children themselves may be encouraged to engage in, with an emphasis on playful and experimental approaches to the performance of gender which allow for gender transgression. The concept implies teachers' consciousness of their own gender behaviors. Simultaneously 
it implies the need for responsiveness to children's gender behaviors in order to open these up. So it has implications for both what is taught and how, for 'pedagogy', the term that incorporates both the implications for teachers and for teaching.

Focusing on gender specifically as an influential aspect of teacher learner relationships, we discuss the possibility for teachers to make interventions in the social reproduction of gendered practices and behaviors of those they teach. Preschool teachers are in a unique position to subvert a continuation of traditionally differentiated gender roles through gender flexible teaching because they have the opportunity to intervene at the very beginning of an individual's educational trajectory, yet this rarely occurs. Our data shows that only two teachers, one in each setting, really tried to challenge traditional gender stereotypes in their thinking and teaching.

There is a long tradition of research within the sociology of education that reveals the intransigence of the gendered nature of educational institutions. In the late 1970s and through the 1980s researchers drew attention to the ways that schools amplify the wider society's ideas about gender roles and "reinforce them in tougher form than they actually exist in the world outside” (Delamont,1980 p4). Even where teachers were explicit about their intentions to challenge gender roles, their management of the children and daily discourse with them betrayed deeper and more habitual practices of gender differentiation (Kamler, 1999). During the 1990s and 2000s the research has proliferated with an ever growing list of gender researchers who have shown how the institutional forces that are embedded in the hierarchical and heterosexist aspects of school, emphasise gender differences (Blaise, 2005; Francis, 1998; Haywood \& Mac An Ghaill, 1996; Skelton, 2001). 
Early childhood education (ECE) is a particularly significant context for exploring the practices that may be associated with the concept of a gender flexible pedagogy. It has been revealed to be a particularly potent location for the entrenchment of gender differences and perpetuation of gender stereotypes between boys and girls as a number of researchers have shown, for example Adriany (2013), Hellman (2012), Yoon (2007), Miu (2005), and Sumsion (2000). ECE is a particularly fruitful ground for the growth of essentialist gender differences for a number of reasons which we will now identify.

Firstly, ECE is very often dominated by a value for a child-centered approach. This value, given critical emphasis by Walkerdine (1998) has spread across the globe (Adriany, 2013; Newberry, 2010). The presence of a strong child-centered discourse means that challenges to the traditional gender order are of secondary importance to following the child's "natural" interests and motivations (Blaise, 2009). Within this ethos there is a tension between challenging the child's construction of the gender binary or following their lead. In addition, many pre-school teachers believe that gender matters are not important to young children, while others argue that young children are too young to be introduced to complex issues such as gender (MacNaughton, 2000).

Another significant reason why ECE is considered to be a fertile ground for the development of traditional, 'essentialist', gender differences is due to the gender imbalance of staff, with men working in a very small minority. The worldwide pattern is for less than $3 \%$ as reported by Brody (2014). Brody also tells us that the proportion of male workers is low across the globe even in countries such as Norway which has had some very deliberate strategies for 
increasing male workers, where only $10 \%$ of staff are male. This pattern of staffing has led to a concern in many countries with the recruitment of more men to work in ECE.

The media-led, problematic discourse of the 'male role model' underlines this debate about bringing male teachers into ECE. It is argued that male teachers can provide 'positive male role models' especially for boys, an idea that has become very popular in policy in recent times, especially in England, a policy rhetoric that has been critiqued by Brownhill, (2014), Adriany, (2013) and many others. The well-established feminist critique of this idea (for example by Martino and Rezai-Rashti, 2012) reveals an underlying assumption that men and women are fundamentally different and that men can therefore bring something distinctive to the field of ECE. The 'male role model' concept is also revealed to be rooted in social learning theory which assumes that the child imitates rather than re-interprets the adult models they are presented with (Skelton, 2001). Our concept of 'gender flexible pedagogy' is aligned with a very different rationale for encouraging men into ECE. We argue that the presence of men working alongside women in ECE settings has the potential for expanding children's understanding and construction of gender so that it becomes less rigid (McCormack \& Brownhill, 2014; Warin, 2006). However, the mere presence of men in ECE is not enough by itself to disrupt gender stereotypes (Sumsion, 2005). What men actually do within their preschool teaching and how they perform gender is a critical consideration for the realization of this potential.

The aim of this paper is to explore how far ECE can become a space to deconstruct traditional gender stereotypes, through gender flexible teaching. The paper is based on two different research studies conducted separately by the authors of this paper. The studies shared the same broad aim to explore the gendered beliefs, assumptions and practices of ECE 
staff. They also shared the same methodological approach to the conducting of dialogic interviews with teachers (Blaise, 2005; Holstein and Gubrium, 1995; Rapley, 2001) where there was an intention to open up a mutual discussion of the possibility of gender flexible teaching and to tease out and challenge gender essentialist assumptions. However, they were conducted in very different locations, (Warin's in Sweden and Adriany's in Indonesia). The authors have engaged in a collaboration created through their participation in the international network of Swedish Research Council funded gender researchers who aimed to examine the conjunction of gender, teaching and care (xx and Gannerud, 2014). We draw together data from both studies to focus on our shared question about how far teachers can deliver gender flexible teaching in their preschool classroom. First we explain what we mean by a 'gender flexible pedagogy’ the key concept in our title.

\section{The concept of a 'Gender flexible pedagogy'}

The concept of a 'gender flexible pedagogy' comes from three sources. Firstly, we need to understand gender as an aspect of identity and this entails a look at broader underlying theories of identity. The authors adopt a poststructuralist idea of identity that challenges essentialist ideas about fixed selves (Davies and Harre, 1990; Gergen, 1991; Kearney, 2003; Warin, 2010) and that understands the social construction of identity as variable and fluid in response to changes in a person's social environment. This recognition of the way that identity adapts to different social and cultural contexts is closely aligned with Butler's ideas about identity as 'performative'.

The second source then is Butler's ideas about the gendered aspect of selves as performed within different cultural environments. Her concept of performativity challenges gender as a 
fixed identity and uncouples gender from sex. She says: "when the constructed status of gender is theorised as radically independent of sex, gender itself becomes a free-floating artifice, with the consequence that man and masculine might just as easily signify a female body as a male one, and woman and feminine a male body as easily as a female one”. (Butler, 1990 p6). This is a radical idea to apply, for example, to debates about proportions of male and female teachers in ECE staff teams where potentially we could understand gender as a 'free-floating artifice'. Butler’s approach to gender as a fluid and free-floating construction implies that an individual's gender performance depends on what options are available to them. If children are provided with rigid options, they are more likely to adopt traditional gender beliefs. Yet if the choices given to them are varied and flexible, they will be more likely to accept and perform flexible gender roles (Bartini, 2006). Löfdahl and Hjalmarsson (2015) for example, describe the strategy used by pre-school staff to dismantle the traditional 'home corner' instead distributing dolls and kitchen utensils throughout the classroom in order to challenge the compounding of the children's gender stereotypical choices about playmates and playthings which had previously led to an entrenchment of gender segregated behaviour with only girls in the home corner.

The third source of this idea, specifically linked to teaching, is the identification of the concept of "gender conscious pedagogy”, a very similar term but one which fails to incorporate a sense of fluid and changeable identities. Eidevald and Lenz Taguchi (2011) discuss 'gender-conscious pedagogy' which they claim is a Swedish concept that does not have an equivalent in preschool pedagogies in other countries. This concept is discussed by Lofdahl and Hjalmarsson (2015) who elaborate it as a means of achieving gender equality. Hellman (2012) and Johansson (2011) have also shown how gender equality is produced through this means within the Swedish context. 
If teachers want to disrupt traditional and rigid gender discourse they must provide children with various alternatives, presented through their own practices and behaviors alongside the resources and learning experiences they provide. In order to create such alternatives they must themselves be highly attuned to gender possibilities as an element of their overall self awareness, a prerequisite for the 'critically reflective emotional professional' as advocated by Osgood (2010:119). They must be alert to the subtle and often invisible ways that traditional gender norms can persist within the power plays of the school. Gender flexible teaching can only be practiced by teachers who are gender aware rather than gender blind (Hogan, 2012).

Several researchers have demonstrated the possibility for ECE to challenge existing gender norms and have worked alongside teachers on initiatives designed with this aim (Davies, 1993, 2003; Marsh, 2000; Rennie, 2003). These researchers illuminate certain strategies and initiatives used by ECE teachers to challenge traditional gender values whilst at the same time expanding children’s understanding of gender discourse. For example, Davies’ undertook her groundbreaking work on challenging young children's gender behaviors within the context of their literacy practices (2003) whilst Rennie (2003) aimed to expand children’s understanding of gender by harnessing the topic of pirates to deconstruct masculine stereotypes. Marsh (2000) collaborated with an ECE teacher to create gender flexible classroom resources, based on Batman/Batwoman, to encourage girls to engage in superhero play.

These initiatives suggest a way forward for a gender flexible pedagogy. This could be practiced by gender activists, both male and female teachers, who are not only attuned to the ways in which traditional gender stereotypes become entrenched within preschool but who 
are also willing to actively resist them. The initiatives described above show how ECE teachers can potentially transform gender discourse in the classroom. They also suggest a model for early education gender researchers to work alongside teachers as 'critical friends' in order to enable the practice of alternative and nontraditional constructions of masculinities and femininities.

Having set out the concept of a gender flexible pedagogy we now move on to examine data from our respective interview studies though this particular lens. We ask the question: How far do ECE teachers go in challenging traditional gender norms within their own pedagogic beliefs and practices?

\section{Background to the two studies}

Indonesia and Sweden provide contrasting locations for the study of gendered practices within ECE. Whilst Indonesia is developing a new interest in and awareness of gender equity and equality by launching the Law of National Education System no 84 regarding Gender Mainstreaming in Education (58/2009), Sweden has a long history of gender awareness and gender sensitive social policy including education, in keeping with other Scandinavian countries (Sundelin, 2008). There is no curriculum obligation for ECE professionals to address gender in Indonesia as there is in Sweden. In addition, there is a long tradition of research on gender in ECE in Sweden but very little in Indonesia. The international network referred to above and funded by the Swedish Research council created a forum for comparing and discussing research on gender and teaching across a range of international early childhood education sites. This discussion forum led to a focus on gender flexible teaching, 
the subject of this paper. It seemed fruitful to compare the gender sensitivity of ECE staff in Indonesia and in Sweden given the contrasting national contexts described above. What the studies have in common is a shared focus on the possibilities for a 'gender flexible pedagogy' discussed in explorative conversations with ECE staff.

All names (of schools, staff and children) have been fictionalized in the following account.

\section{Indonesian teacher perspectives}

\section{Background to the study and participants}

Several studies have concluded that gender construction in Indonesia is the result of interplay between politics and religious discourse (Blackburn, 2004; Oetomo, 2000; Parker, 1992; Robinson \& Bessell, 2002). Religion exerts a powerful reinforcement of a traditional gendered division of labour since it emphasizes the 'essential' different characteristics of men and women based on their biology and encourages a faithfulness to men's and women's ‘true’ natures (Yulandissari, 2006). X’s research purpose was to gain a deep understanding of day-to-day practices of gender related behaviors and practices within a kindergarten in Indonesia. She conducted an ethnography in one particular kindergarten, Kopo kindergarten located in the city of Bandung, reported in Adriany (2013). Adriany adopted a participant observer position in the field (Hammersley \& Atkinson, 2007) which enabled her to hold informal discussions with teachers referring to classroom practices and specific incidents, assuming the role of 'critical friend'. She also undertook more formal one-to-one interviews with the staff. 
There were 4 teachers, all female, responsible for 28 children, aged 2-6, divided into three different age groups. The teachers were addressed as "Bunda”, a term normally used to address a mother in Indonesia, and widely used in Indonesian preschools. The teachers in this study were Bunda Sari, Bunda Siti, Bunda Intan and Bunda Euis. X 's data from teachers was in the form of transcriptions of audio recorded interviews and in field notes. It was incorporated into her overall analysis of her ethnographic data. She adopted a constructivist grounded theory approach based on Charmaz (2006) using an 'open coding ' process followed by a 'focused coding' which compared the data through constant comparison to produce a refined set of conceptual categories which included the key concept of gender flexible teaching. The findings presented in this paper are confined to analysis of the interviews and informal discussions that took place with staff since this paper is concerned with ECE staff perspectives on the possibility for gender flexible practices in their pedagogy.

\section{Findings: Accounts of gendered teaching practices}

Findings from this study suggest that in general the teachers' accounts of their practices and underlying assumptions were highly gendered. The teachers made a clear differentiation between boys and girls in the classroom, responding to them differently and holding different expectations about their interests and needs. For example, the school used different pictorial symbols for boys and girls placing flower pictures on the girls' lockers and bug pictures on the boys' lockers. They also used a colored ticket to administer their system of 'free choice time’ with pink tickets for girls and blue tickets for boys. When the teachers at Kopo kindergarten made materials for girls and boys, they often differentiated the items, as shown in the following: 
Bunda Siti is preparing special hats for the children. The school's theme for the week is International Culture with special reference to Chinese Culture, so the hats are Chinese. Interestingly, the teacher makes two different types of hats for boys and girls. Boys' hats are triangle shapes while the girls' hats resemble a tiara. (Field notes, $17^{\text {th }}$ May 2010. Translated into English)

Adriany’s interviews with the Kopo teachers revealed how their gendered practices were influenced by their underlying assumptions about gender differentiation subscribing to implicit ideas about biological essentialism. As Bunda Sari said in one of her interviews:

I think, in the long term children need to understand that they are girls or boys and it should be taught by us, from the way we treat them. We should treat boys like boys and treat girls like girls. Then they'll learn how to behave like girls or boys. Therefore, as teachers, we have to be very careful in deciding which colour is suitable for boys and which one is suitable for boys and girls. That's what I think.

This biological argument, that was deeply embedded in the school's practices, was strongly associated with religious discourse. Given that Indonesia has the largest Muslim population in the world, Islamic religious discourse is pervasive. The teachers frequently used the concept of “kodrat”, originally an Arabic word, meaning the 'innate', 'essential' and unchangeable characteristics of a person. Yulindrasari and McGregor (2011) believe the discourse of kodrat has been embodied in gender discourse in Indonesia, referring to 'natural' and fixed characteristics (Yulindrasari, 2006, p. 10) showing an interdependence between biological and religious essentialism (Adriany, 2013). Wieringa (2003) argues further that within the notion of kodrat, whilst it regulates both men and women, it particularly emphasizes the role of the woman as wife and mother. Suryakusuma (1987) asserts that the 
notion of kodrat has been used by the new-order regime in Indonesia to prevent women from becoming politically active because of a fear this would challenge the status quo, as indeed it did in the 1960s when they were. Consequently, this notion of kodrat has been widely circulated. It is passed on, not through explicit curricular teaching, but implicitly within the popular discourse of the family and clearly portrayed in the media, for example in magazines and movies, perpetuating the domestication of women. This too was evident in the school, for example Bunda Siti argued:

Yes, as I said today things have changed. In terms of occupation, women can do men's job and vice versa, but we have to keep in mind our "kodrat" as a woman.

The kodrat concept is also applied to the child and supports the strong child-centred approach that was upheld in Kopo (Warin and Adriany, 2014) emphasizing the principle that the child's essential character should not be disturbed or forced. This belief meant that the teachers felt they should not use their professional power to challenge children's traditional gender practices. As Bunda Siti asserted:

Maybe each child has a different character because we don't want to force children to follow us. I think it's children's characters.

\section{A dissenting Voice: A possibility for delivering gender flexible teaching}

Even though the findings indicated that the majority of the teachers upheld strong gender essentialist beliefs they did not all agree that boys and girls should be treated differently. For example, Bunda Intan, the youngest teacher in the school, did not support different treatment for boys and girls. Her dissenting voice showed that Kopo kindergarten teachers' voices 
cannot be reduced into a single voice and that multiple meanings of gender beliefs co-existed in the school. As she said:

(laugh) I don't know, I just don't understand. Is being a boy or a girl only determined by the colour they choose, the toys they play with, the way they talk or what? Can boys pick up pink? I think they can. I am wondering whether such a distinction for boys and girls is necessary? If boys like to play with Barbie, what's wrong with that? Barbie can be good sometimes.

Bunda Intan also argued that children need to expand their understanding of gender. She said further in her interview:

I think for children in early years, we just give anything, everything to children. Let them explore. Don't differentiate them... That's why, when I heard about Akang [3 year old boy], who likes pink and occasionally wear girls’ clothes, I think he’s just exploring.

Bunda Intan's statement showed the degree to which she understood the fluidity and flexibility of gender and the importance of expanding children's gender construction. Her description of Akang’s ‘exploring’ implies her understanding of gender as 'free-floating artifice' in the way that Butler has presented it (1990 p6). This idea is particularly challenging to many ECE staff in Indonesia where religion and politics exert a powerful influence in maintaining an essentialist binary construction of man and woman, masculinity and femininity. Intan however discussed the possibility of teachers countering traditional gender discourse. An interest in gender was stimulated through her involvement in Adriany’s study. She was particularly receptive to Adriany's challenges to the traditional gender order 
and Adriany’s modelling of gender flexible pedagogy in her own behavior as participant observer with children. For example on one occasion Adriany gently rejected a child's request for her to take on the role of a princess and instead Adriany assumed the role of a space warrior. More than the other teachers Intan was willing to engage in such challenges herself and learn from the ‘critical friendship’ of Adriany as she worked alongside teachers in the classroom. Intan's interest in gender, and her desire to adopt a more challenging approach than her colleagues, continued after the end of this study when she chose to write an undergraduate dissertation on gender sensitive teaching in early childhood education as part of the degree she was studying alongside her professional employment.

However, Bunda Intan’s views were exceptional and the analysis showed a clear pattern of beliefs about innate gender differences combined with religious beliefs about each child's essential nature. The child-centred approach adopted within the school meant that teachers did not feel they should interfere with nature. Educational values compounded religious values with the outcome that gender flexible teaching was not the norm in this kindergarten.

\section{Swedish teacher perspectives}

\section{Background to the study and research participants}

Warin, a UK researcher, was interested in the strong UK view, perpetuated in the media, that young children especially boys need "male role models". Her theoretical critique of this assumption influenced by Skelton (2001) and by Martino and Rezai-Rashti (2012) amongst others, led to the formation of the network, referred to above, with Swedish researchers and others who were similarly interested in gender pedagogies in early childhood education. This forum produced the opportunity to contact preschools in Gothenburg and carry out interviews with ECE teachers there in April/May 2012. Warin chose to interview male teachers since 
their minority status within the ECE workforce might imply the likelihood of a gender consciousness.

Five teachers agreed to be interviewed: Jonas, Linus, Karl, Per and Geir. Four were working in preschools and a fifth (Geir) had worked as a preschool teacher for ten years and had then become a lecturer in teacher education. The interviews were all conducted in the men's workplaces, audio recorded and then transcribed. They followed the phenomenological research tradition, aiming to access the men’s experiences of and perceptions about, their professional preschool lives. The interviews were dialogic and reciprocal (Blaise, 2005; Holstein \& Gubrium, 1995; Lather, 1991) driven by the researcher’s intention to gain insight into these men's gender awareness (or gender blindness) in tandem with the men’s own agendas and interests within the broad topic of gender concerns in the preschool. Specific questions were asked about the men's implicit theories of gender in relation to being male teachers of this age group. What had motivated the adoption of this professional role? How far were they trying to model gender flexibility? Or was gender perhaps quite low down their list of priorities within their teaching aims? Following transcription, the five stages of data analysis were then undertaken according to the procedure devised by Smith, Flowers, and Larkin (2009), known as interpretative phenomenological analysis (IPA). IPA is particularly suited to phenomenological studies such as this one where the intention is to examine how the participants make sense of their experiences, and is particularly appropriate for small samples where there is an intention to do justice to each participants account (Smith \& Eatough, 2006). Nine cross themed connections emerged: entry into career, adult gender roles, beliefs about children and childhood including an emphasis on freedom and choice, playfulness and play, vocational motivation, gender knowledge and sensitivity, sources of encouragement, the preschool as a mini society, strategies for workforce change. 
The data selected for this paper focused particularly on the 'gender knowledge and sensitivity’ theme.

How far did the research participants articulate accounts of their practices that showed an intention to subvert traditional gender patterns? How far could their teaching, according to their own accounts, be described as gender flexible?

\section{Findings. Gender sensitivity and the management of identity presentations within the preschool}

Familiarity with the gender principles in the preschool curriculum.

The first point of interest is that all the men made statements that showed a clear awareness of the explicit gender goal that is enshrined within the Swedish curriculum: 'The preschool should counteract traditional gender patterns and gender roles' (Skolverket, 2011, p. 4). As an English researcher with familiarity of ECE Warin made implicit comparisons with the English context where the Early Years Foundation Stage (EYFS) curriculum has no such explicit statement about gender. However, having a statement enshrined in the curriculum is one thing but it is quite another to find that staff are necessarily aware of and practicing according to such principles. The men's readiness to display their knowledge of the gender principles in their curriculum suggested quite a high degree of gender consciousness.

The men’s familiarity with this preschool curriculum goal was expressed in various ways. For example Karl volunteered that the Swedish preschool curriculum requires active work 
against gender (his emphasis) and Geir stated, emphatically, “we need to teach gender in preschool ". Per also mentioned that he was very much aware of this element of the curriculum, especially because parents frequently asked him about this aspect of his teaching and wanted to monitor it. Linus pointed out that although the resources in his Montessori preschool were gender neutral he was able to challenge gender roles through his influence on peer group formation and free play. Even Jonas made a statement showing an implicit sensitivity to this aspect of the preschool curriculum. This was particularly noteworthy since he had received no formal training, and therefore no input on gender in the curriculum:

"Although this is in the curriculum - nobody checks up. But you have to check up on yourself I think"

This particular group of men were very much aware of the Swedish curriculum statement on counteracting traditional gender behavior, a possible indication of their gender awareness and sensitivity.

\section{Gender consciousness and gender essentialism}

A second point of significance is that two of the men, Karl and Geir, were both engaged in the academic study of gender and teaching, Karl as a postgraduate student and Geir as a lecturer. Consequently, they might be expected to be highly gender conscious individuals and the analysis showed this was indeed the case. For example, in his teacher training role Geir was aware of the need to sensitize both male and female trainees to gender issues and 
explained that he used various deliberate strategies to achieve this aim. At the time of the interview, Karl was undertaking postgraduate study alongside his classroom teaching role and was very interested in theories about gender, especially masculinities, and flexible identities drawing on the work of (Connell, 1995). He discussed this in relation to a 'line' or continuum of masculinity where he placed his personal hobby of kick-boxing at the 'male end' and some aspects of his role as kindergarten teacher as 'closer to the female'.

The men were very much aware of the current discourse, especially strong in England but pervasive in many other countries including Sweden about the need to model certain types of traditional masculinities to compensate for absent fathers. Yet these men did not express such a value as governing their own practices. Indeed they were keen to describe the ways they performed non-traditional, gender flexible practices in front of their 'audience' of children. For example Karl told Warin that he believed it was important that the children should witness him changing the diapers of the infants in his care, and Linus was deliberate in his intentions to have the children witness his laying of the table before the midday meal: “They see me laying the table and doing everything that women teachers do'. Their accounts emphasize their deliberate performance of transgressive gender illustrating practice that is consistent with Butler's emphasis on gender as socially constructed and socially performed.

At a couple of points in the interview Karl mentioned that his masculine behavior was learned , a term he emphasized, as in the following claim: ' I believe I have many classical masculine qualities but this is what I have learned'. This was consistent with his overview of himself as having changeable and situation-specific identities. Karl also had a strong belief that gender is socially constructed, which matched his belief that none of his identities are fixed and essential. He mentioned his 'changing identities: being a child, an adult, a male, 
female, a teacher, a student'. He was aware of these different identity presentations in front of his different audiences, especially the children as observers and interpreters of information about gender within their environment.

Yet it is important not to oversimplify the gender awareness of these five individuals. Karl's statement above about his ‘classical masculine qualities' betrays an ambivalence about the possibilities of gender transgression. This internal tension and contradiction was shown in his response to questions about doll play:

Warin. Do you ever demonstrate doll play to the children?

K. Yes. I do. But I prefer to play adventure games with them [dolls] rather than to play 'house'. It doesn't come naturally to me to play with dolls but if someone is sitting down playing with a doll then I can join in. I can do this.

So, despite Karl’s clear statement that he has “learned” classical masculine qualities, which suggests he does not subscribe to a biological essentialist belief about gender differences, nevertheless it is interesting to see the word 'naturally' is slipped into his statement, a word which betrays an assumption that he believes he has some essential gendered predispositions.

\section{Methodological insights suggesting gender consciousness}

Warin's analysis also harnessed the important tool of researcher reflexivity and examined the interactional nature of the interview conversations, including her own questions and contributions. This was enlightening with view to the men's gender awareness. So, a final point about evidence of gender sensitivity concerns the gender positions that were taken up 
and negotiated within the interview itself. For example in response to a 'Devil's advocate' question about rough and tumble play (a term that is often used to describe men's play with young children) Linus quickly pointed out that he is not 'rough' but 'tender' and added 'I like small children... I can calm them'. Some of the men were highly aware of gender, and able to perform gender sensitivity in their presentation of self within this co-constructed conversation since gender was an explicit element of, and raison d'etre for, the interaction. It is interesting to speculate how a more 'gender blind' participant might have responded to the same questions.

So overall, through the positions taken up within the interview and the values and views described as part of the joint discussions, the men displayed a consciousness of the ways they were manifesting gendered behaviors within the preschool.

\section{Discussion: From gender blindness to gender consciousness.}

So what have both studies revealed to us about the possibility and practicality of what we have termed gender flexible teaching? Clearly both studies are concerned with small samples so the conclusions we draw are necessarily exploratory. In addition there are differences between the studies with respect to design and the gender composition of the samples: allfemale in the Indonesian study and all-male in the Swedish study. However, the studies are comparable with respect to their authors' purposes to reveal the potential for a 'gender flexible pedagogy' in discussions with ECE staff. Taken together the studies show that there are certainly cases of teachers who are very sensitive to gender matters within their own teaching relationships and who have ideals about developing the children they work with so that they are much less constrained by traditional and rigid forms of gender. In Adriany’s study it was Bunda Intan who was willing to transgress gender norms and who was 
supportive of children who did not conform to gender stereotypical behavior in their choices of toys and colours. In Warin's study it was Karl who described his own intellectual interest in gender and education which informed his gender sensitivity and consequent experimentation in 'troubling' gender (Butler, 1990).

In comparing the two research contexts we can see that a very significant influence on the gendered practices of the staff concerns the underlying beliefs they hold about gender, particularly the gender essentialist views of most of the Indonesian staff and the social constructivist views articulated by the Swedish staff.

The gender beliefs that were expressed to us and that shaped the preschool pedagogy and practice were formed through the participants’ immersion within the cultural, political and religious context of their different countries. In Indonesia, it is only recently that educational policy makers have begun to address gender equality with a new programme entitled Gender perspective school programme (aimed at primary school children upwards). By contrast Sweden is famed internationally for its longstanding progressive focus on gender within the related social policy areas of childcare and education. It is not surprising therefore to find that Warin's participants were, on the whole, much more "gender sensitive”.

We could suggest that by contrast Adriany's participants were 'gender blind', in the Indonesian study. Here we are using the term as defined in the European Commission glossary of gender equality to mean 'the failure to recognise that gender is an essential determinant of social outcomes impacting on projects and policies’ (http://ec.europa.eu/justice/gender-equality/glossary/index_en.htm). However, this rather simplistic contrast does not actually represent the women working in Kopo kindergarten. 
They were not gender blind but rather the majority of them held a very particular set of assumptions about gender differences, rooted in an unquestioned essentialism. The differences in the practices reported and rationalised to Adriany and those described to Warin illustrate how deeply implicit assumptions about gender are manifested in classroom day-today practices and behaviours.

When do implicit assumptions about gender become critically available to a person and therefore transformable into explicit theories? We could look at Bunda Intan (in Adriany’s study) and at Karl and Geir (in Warin’s study ) as living examples of a transformation from gender blindness to gender consciousness. For these three individuals their gender consciousness has been developed, and continues to develop, through their critical engagement with academic gender studies and also through their participation in gender focused research. In their practices as preschool teachers we see a living struggle to challenge themselves and the children they teach in the ways they perform gender.

\section{Conclusion}

It is both possible and desirable to train children and young people to become much more alert to the ways in which they themselves and other people around them are performing and thereby creating gender identities. If we are to tackle gender within ECE we need to advance on two fronts simultaneously: developing gender conscious pedagogues and a gender sensitive curriculum. In order to be able to confront and disrupt gendered performances in children we have to develop greater gender sensitivity ourselves as educators (Houston, 1985). For example we have to notice gender stereotypical behaviours and then we have to find thoughtful ways to challenge and expand them. X's study implies a possible route to increasing gender sensitivity in ECE teachers through working alongside a gender-conscious 
‘critical friend’. As Rogers (1967) points out only self-aware teachers can bring about selfawareness in pupils. The explicit development of gender sensitivity has to become a key element of initial teacher training and continuing professional development if we want to disrupt the slow but steady progress of gender entrenchment.

This paper has argued that we need a workforce in early childhood education who can create gender flexible identities in their relationships with young children. The principle, that we have termed 'gender flexible pedagogy', has the potential to 'undo' the establishment of traditional gender performances and practices through an explicit focus on the creation of gender consciousness and gender activism. We need to take Butler's ideas on board within the training of those who teach and care for young children, recognising the implications of her theories for 'troubling' gender, for resisting traditional performances of gender and subverting them through the creation of gender flexibility.

\section{References}

Adriany, V. (2013) Gendered Power Relations within Child-Centred Discourse: An Ethnographic Study in a Kindergarten in Bandung, Indonesia. (PhD Thesis) Lancaster University, Lancaster, England.

Adriany, V. and Warin, J. (2014) 'Preschool teachers' approaches to gender differences within a child-centered pedagogy: findings from an Indonesian kindergarten' International Journal of Early Years Education, vol 22, no. 3, pp. 315328., 10.1080/09669760.2014.951601 
Bartini, M. (2006) Gender role flexibility in early adolescence: developmental changes in attitudes, self-perception, and behaviors. Sex Roles, 55, 233-245.

Blackburn, S. (2004). Women and The State in Modern Indonesia. Cambridge: Cambridge University Press.

Blaise, M. (2005) A feminist poststructuralist study of children “doing” gender in an urban kindergarten classroom. Early Childhood Research Quarterly, 20(1), 85-108. doi: 10.1016/j.ecresq.2005.01.002

Blaise, M. (2009) "What a Girl Wants, What a Girl Needs”: Responding to Sex, Gender, and Sexuality in the Early Childhood Classroom." Journal of Research in Childhood Education, 23 (4):450-460.

Brody, D. (2014) Men who teach young children: An international perspective. London: Trentham Books, Insitute of of Education Press.

Brownhill, S. (2014) 'Build me a male role model!' A critical exploration of the perceived qualities/characteristics of men in the early years (0-8) in England. Gender and Education, 26 (3) p 246 - 261.

Butler, J. (1990) Gender Trouble. New York: Routledge.

Charmaz, K. (2006) Constructing Grounded Theory: A Practial Guide Through Qualitative Analysis, London: Sage.

Connell, R. W. (1995) Masculinities. Cambridge: Polity Press.

Davies, B. (2003) Shards of Glass: Children Reading and Writng Beyond Gendered Identities Cresskill: Hampton Press.

Davies, B and Harre, R (1990) Positioning: the discursive production of selves. Journal for the Theory of Social Behaviour. 20 (1) p43-63

Delamont, S. (1980) Sex roles and the school. London: Methuen 
Eidevald, C. \& Lenz Taguchi, H. (2011).Genuspedagogik och förskolan som jämställdhetspolitisk arena (Gender conscious pedagogy and preschool as an arena of gender equality politics. In H. Lenz Taguchi., L. Bodén. \& Ohrlander, K. (Eds.). En rosa pedagogik - jämställdhetspedagogiska utmaningar (Pink pedagogy - challenges to pedagogy of gender equality (19-31) Stockholm: Liber.

Emerson, R. M., Fretz, R. I., and Shaw, L. L. (1995) Writing Ethnographic Fieldnotes. Chicago and London: The University of Chicago Press.

Francis, B. (1998) Power Plays: Primary School Children's Construction of Gender, Power and Adult Work. Staffordshire: Trentham Books Limited.

Gergen, K J (1991) The Saturated Self. New York: Basic Books. 1 - 281

Hammersley, M., and Atkinson, P. (2007) Ethnography: Principles in Practices (Third edition ed.). New York: Routledge.

Haywood, C., and Mac An Ghaill, M. (1996) Schooling Masculinities, in: Understanding Masculinities. Buckingham: Open University Press. 1-222.

Hellman, A. (2012) Democracy among girls and boys in Pre- school: inclusion and common projects. In E. Johansson and D. Berthelsen (Eds.), Spaces for Solidarity and Individualism in Educational Contexts (pp. 99-114). Gothenburg. Swedia: ACTA Universitasis Gothoburg.

Ho, E. (2014) Men in Early Childhood Education in Singapore. Retrieved 3rd Juy, 2014, from http://www.arnec.net/cos/o.x?c=/ntuc/pagetree\&func=view\&rid=1036916 Hogan, V. (2012) Locating My Teaching of Gender in Early Childhood Education Teacher Education Within The Wider Discourse of Feminist Pedagogy and Poststructuralist Theory. Paper presented at the the Joint AARE/ APERA, Sydney.

Holstein, J. A., and Gubrium, J. F. (1995) The active interview. London: Sage. 1 - 85 
Houston, B. (1985) Gender Freedom and the Subtleties of Sexist Education. Educational Theory, 35(4), 359-369.

Kamler, B. (1999) Constructing Gender and Difference. Critical Research Perspective on Early Childhood. New Jersey: Hampton Press Inc.

Kearney, C. (2003) The Monkey's Mask: identity, memory, narrative and voice. Stoke-on-Trent: Trentham. 1- 188.

Lather, P. (1991) Getting smart: Feminist research and Pedagogy with/in the Postmodern. New York: Routledge.

Löfdahl, A and Hjalmarsson, M. (2015) Children's interpretive reproduction of gender conscious didactic agendas in a Swedish pre-school. In S.Brownhill, J. xx and I. Wernersson (Eds.), Men, masculinity and teaching in early childhood education: international perspectives on gender and care. London: Routledge.

MacNaughton, G. (2000) Rethinking Gender in Early Childhood Education. New South Wales: Allen and Uwin.

Majzub, R. M. (n.a). Critical Issues in Preschool Education in Malaysia Recent Advances in Educational Technologies. http://www.wseas.us/elibrary/conferences/2013/CambridgeUSA/EET/EET-26.pdf

Marsh, J. (2000) ‘But I want to fly too!’: Girls and superhero play in the infant classroom. Gender and Education, 12(2), 209-220. doi: 10.1080/09540250050010018 Martino, W. and Rezai-Rashti, G. (2012) Gender, Race and the Politics of Role Modelling. New York: Routledge.

McCormack, O. and Brownhill, S. (2014) 'Moving away from the caring': exploring the views of in-service and pre-service male teachers about the concept of the male 
teachers as a role model at an early childhood and post-primary level. International Journal of Academic Research in Education and Review, 2(4), 82-96.

Miu, L. (2005) Exploring teachers' understanding and practice of gender equity : case study of a kindergarten in HongKong. (Master of Education Dissertation presented a part fulfilment of the requirements of the degree of Master of Education), The University of Hongkong, Hongkong. Retrieved from http://hdl.handle.net/10722/25711

Newberry, J. (2010) "The global child and non-governmental governance of the family in post-Suharto Indonesia." Economy and Society, 39 (3):403-426.

Oetomo, D. (2000). Masculinity in Indonesia: Gender, sexualities, and identities in changing society. In R. Parker, R. M.Barbosa, \& P. Aggleton (Eds.), Framing the sexual subject: The politics of gender, sexuality, and power. Berkeley: University of California Press.30- 46

Osgood, J. (2010) Reconstructing professionalism in ECEC: the case for the 'critically reflective emotional professional'. Early Years: An International Research Journal, 30:2, $119-133$.

Rapley, T.J. (2001) The art(fulness) of open-ended interviewing: some considerations on analysing interviews. Qualitative Research, 1 (3), 303-323.

Rennie, L. J. (2003) "Pirates can be male or female": investigating gender-inclusivity in a years 2/3 classroom Research in Science Education, 33, 515-528.

Robinson, K., \& Bessell, K. (2002). Women in Indonesia: Gender Equity and Development. Singapore: ISEAS.

Rogers, C. R. (1967) A Therapist's View of Psychotherapy. London: Constable.

Skelton, C. (2001) Schooling the Boys: Masculinities and Primary Education. Buckingham: Open University Press.

Skolverket, S. (2011) Curriculum for the preschool Stockholm: Skolverket. 
Smith, J. A., and Eatough, V. (2006) Interpretative phenomenological analysis. In G. M. Breakwell, S. Hammond, C. Fife-Schaw and J. A. Smith (Eds.), Research methods in psychology (3rd Edition ed., pp. 322-341). London: SAGE.

Smith, J. A., Flowers, P., and Larkin, M. (2009) Interpretative Phenomological Analysis : Theory, Method and Research. London, California, New Delhi, Singapore: SAGE Publications Ltd.

Sumsion, J. (2000) Negotiating Otherness: a male early childhood educator's gender positioning. International Journal of Early Years Education, 8(2), 129-140.

Sumsion, J. (2005) Male teachers in early childhood education: issues and case study. Early Childhood Research Quarterly, 20(1), 109-123. doi: 10.1016/j.ecresq.2005.01.001

Sundelin, J. (2008) Play: The Swedish Way,. The Guardian Newspaper, Society Guardian (Tueday, 11th March)

Suyatno. (2004) Analisis Kesenjangan Gender pada Aspek Kebijakan, Kurikulum dan Sumberdaya Manusia pada Pendidikan Taman Kanak-kanak (TK): Studi di Kota Semarang-Jawa Tengah (Analysis on Gender Discrepancies in Kindergarten's Policies, Curriculums and Human Resources: A Study in Semarang-Central Java. Semarang: Universitas Dipenogoro.

Svalyerd, K. (2007) Genuspedagogik (Gender conscious pedagogy) Stockholm: Liber. UNESCO. 2007. Strong Foundation for Gender Equality in Early Childhood Care and Education. Bangkok: UNESCO Asia and Pacific Regional Bureau for Education.

Walkerdine, V. (1998) "Developmental psychology and the child-centered pedagogy: the insertion of Piaget into early education." In Changing the subject: psychology, social regulation, and subjectivity, Edited by: Henriques, J., Hollway, W., Urwin, C., Venn, C. and Walkerdine, V. 153-202. London: Routledge. 1- 345.

Wieringa, S. (2003) The birth of the new order state in Indonesia: sexual politics and nationalism. Journal of Women's History, 15(1), 70-91. doi: 10.1353/jowh.2003.0039 
Yoon, J. (2007) A Case Study of Korean Girls' Constructions of Girlhood in a Kindergarten Class. (PhD Dissertation), The University of Texas at Austin.

Yulindrasari, H. (2006) Gendered parenting in Indonesian Magazine: A Discourse Analysis of Ayah Bunda. (Master Thesis), Melbourne, University of Melbourne.

Yulindrasari, H., and McGregor, K. (2011) Contemporary Discourses of Motherhood and Fatherhood inAyahbunda, a Middle-Class Indonesian Parenting Magazine. Marriage and Family Review, 47(8), 605-624. doi: 10.1080/01494929.2011.619304

Warin, J. (2010) Stories of self: tracking children's identity and wellbeing through the school years, Stoke-on-Trent: Trentham. 1- 212.

Warin, J. (2006) Heavy-metal Humpty Dumpty: dissonant masculinities within the context of the nursery. Gender and Education, 18(5), 523-537. doi: 10.1080/09540250600881683 Warin, J. (2013) The status of care: linking ‘educare’ and gender, The Journal of Gender Studies. 23: 1.93 - 106. DOI:10.1080/09589236.2012.754346.

Warin, J. and Gannerud, E. (2014) Gender, teaching and care: a comparative conversation. Editorial. Special Issue of Gender and Education. 26 (3) 193- 200. 